\title{
THE USE OF RADIOACTIVE CHROMIUM 51 AS AN ERYTHRO- CYTE TAGGING AGENT FOR THE DETERMINATION OF RED CELL SURVIVAL IN VIVO ${ }^{1,2}$
}

\author{
By FRANKLIN G. EBAUGH, JR., 8 CHARLES P. EMERSON, AND JOSEPH F. ROSS \\ WITH THE TECHNICAL ASSISTANCE OF ROSE ALOIA, PEARL HALPERIN, \\ AND HELEN RICHARDS
}

\begin{abstract}
(From the Robert Daweson Evans Memorial Laboratory, Massachusetts Memorial Hospitals, and the Department of Medicine, Boston University School of Medicine, Boston, Mass.)
\end{abstract}

(Submitted for publication May 27, 1953; accepted August 18, 1953)

One of the most useful methods available for the quantitative measurement of hemolytic rates in clinical subjects and for the evaluation of red cell viability after storage is based on the survival of transfused erythrocytes. Access to such data, however, has been restricted because of limitations in the methods hithertofore available for measuring red cell survival in vivo.

The differential agglutination method of counting donor cells, the procedure most commonly employed, has limitations in that large transfusions are required; the donor blood must be devoid of all antigenic isoagglutinins which are not likewise possessed by the recipient; the recipient's cells must contain agglutinogen $\mathrm{A}$ or $\mathrm{B}$ or $\mathrm{M}$ or a combination of the three agglutinogens which is not contained in the donor blood; and, finally, this method excludes the use of autotransfusion, which would eliminate the risk of transmission of hemologous serum jaundice.

The labelling of donor cells with radioactive iron $\left(\mathrm{Fe}^{55}\right)$ permits the conduct of survival studies on a short term basis (1-3) but re-utilization of radioactive iron released from hemolyzed donor cells and the subsequent incorporation of this label in the recipient's red cells preclude its use in studies extending for periods longer than 24 to 48 hours.

\footnotetext{
1 This work was supported in part by a contract between the Atomic Energy Commission and the Massachusetts Memorial Hospitals, and funds from the American Cancer Society of Massachusetts, Inc., Boston Blood Grouping Laboratory.

2 Presented in part before the Committee on Blood and Related Problems, National Research Council, Washington, D. C., September 17, 1952, and the American Federation for Clinical Research, Eastern Section, Boston, Massachusetts, April 16, 1953.

8 Part of this work was performed while a Public Health Service Research Fellow of the National Cancer Institute.
}

Furthermore, this method requires the accumulation in the prospective donor of radioactive iron in relatively high concentration, a procedure which is not desirable. Other tagging methods that have been described, involving the use of sulfhemoglobin (4), $\mathrm{N}^{15}$ (5), $\mathrm{C}^{14}$ (6), $\mathrm{P}^{32}$ (7), and $\mathrm{Zn}^{65}$ (8), are similarly objectionable from one or another standpoint.

Gray and Sterling $(9,10)$ have demonstrated that a firm union between erythrocytes and chromium can be established in vitro with great rapidity and with no apparent damage to the exposed cells. These observations imply that radioactive chromium might serve admirably, not only as a tagging device for measuring circulating red cell volume as proposed by these authors, but as a basis for measuring red cell survival in vivo. The potential advantages of its use in this manner are several :

1. By reinjecting chromium-tagged red cells into their original host, i.e., autotransfusion, it might be possible to measure the longevity of erythrocytes in their native environment. Such an approach would extend the application of this type of study to hemolytic disorders based on inherent red cell defects which are not amenable to investigation by transfusion, and would insure the validity of survival data in all types of cases.

2. This method may provide a simple and definite method of evaluating the effectiveness of methods and media for in vitro preservation of erythrocytes in stored blood. Relatively small samples of donor blood might suffice for accurate counting after injection. A reduction in volume of injected material might be achieved to the extent that several aliquot samples from one unit of blood might be transfused after successive intervals 
of storage, or after storage under a variety of conditions, affording a more accurate basis for studying the rate of deterioration of preserved red cells.

3. By substituting autotransfusion for transfusions in survival studies, the risk of infection, including hepatitis, and the danger of isoimmunization in the recipient are excluded.

It has been reported $(9,10)$ that erythrocytes bind 80 to 90 per cent of sodium chromate $\left(\mathrm{Na}_{2} \mathrm{Cr}^{51} \mathrm{O}_{4}\right)$ when trace amounts of the latter are added to cell suspensions in vitro, the globin portion of the hemoglobin molecule being the site of the combination. These observations have been amplified and extended by a series of experiments designed to determine:

(1) The effect of storage on the kinetics of chromium uptake by erythrocytes;

(2) the influence of chromium, and the effect of the conditions imposed by the labelling procedure, on the post-transfusion of red cells exposed to this metal in vitro;

(3) the avidity and stability of the linkage between erythrocytes and chromium; and

(4) the degree to which sodium chromate released from hemolyzed red cells becomes incorporated into other circulating red cells, or into red cells subsequently produced by the bone marrow of the recipient, the occurrence of which would invalidate red cell survival data obtained by this tagging procedure.

\section{METHODS}

\section{Preparation and administration of $\mathrm{Na}_{2} \mathrm{Cr}^{\mathrm{B1}} \mathrm{O}_{4}$ labelled blood}

Donor blood used in these experiments was collected and stored in collapsible bags constructed of polyvinyl plastic 4 containing $75 \mathrm{ml}$. of acid-citrate-dextrose (ACD) solution N. I. H. Formula A.s Donor red cells were tagged with radioactive chromium ${ }^{6}$ by introducing 3 to 5 ml. of an aqueous solution containing $\mathrm{Na}_{2} \mathrm{Cr}^{61} \mathrm{O},(\mathrm{pH} 6.0$ to 8.0 ) and with a specific activity of 0.25 to 1.0 millicuries per mg. of chromium metal followed by approximately 10 volumes of isotonic saline into the plastic donor tubing connected to the bag containing whole blood and

\footnotetext{
4 "Blood Packs" distributed by Fenwal Laboratories, Inc., Framingham, Massachusetts.

- Seventy-five ml. of this solution contains trisodium citrate, $1.65 \mathrm{Gm}$., citric acid, $0.60 \mathrm{Gm}$., and dextrose, 1.84 $\mathrm{Gm}$.

- Obtained from Abbott Laboratories, North Chicago, Illinois. We wish to express our gratitude to Dr. Donalee Tabern for his kind cooperation.
}

ACD diluent. $\mathrm{Na}_{2} \mathrm{Cr}^{61} \mathrm{O}$, should not be autoclaved when mixed with $A C D$ solution, since it will decompose under these conditions and become incapable of labelling erythrocytes. The contents of the bag were thoroughly mixed and equilibration of the blood and chromium salt allowed to proceed for various periods of time and under a variety of conditions which are specified in Table I. The bloods of Experiments 1 and 2 were continually agitated on a mechanical shaker during the period of equilibration; the bloods for all the other experiments were gently mixed by inversion every 10 to 20 minutes during the equilibration period. Final preparation of the tagged blood for injection included the preliminary separation of cells and plasma by rotation at $2000 \mathrm{rpm}$. in an International Centrifuge (Model B. P.) for 30 minutes at room temperature, followed by the removal of approximately 30 to 85 per cent of the plasma. In Experiments 1 and 2 the tagged red cells were washed once in their native plasma. In Experiment 3, the donor cells were suspended in saline, equilibrated with $\mathrm{Cr}^{61}$, washed and finally resuspended in saline before injection. These procedures were calculated to insure the maximum degree of chromium binding with least exposure to damage by the erythrocytes, and reduction to a minimum of the extra-corpuscular chromium in the injected mixture.

The first series of transfusions (Series I, Experiments 1-9) involved the injection of normal donor blood which had been stored at 4 to $6^{\circ} \mathrm{C}$. for 0 to 26 days, then tagged with $\mathrm{Na}_{2} \mathrm{Cr}^{51} \mathrm{O}_{4}$ by the method described above. Recipients were healthy medical students, each of whom was subjected to a $500 \mathrm{ml}$. phlebotomy immediately before transfusion. 'None of these subjects, with one exception, had been transfused previously; (Subject $C N$ had received experimental transfusions on three occasions during the preceding two years).

Individuals receiving experimental transfusions in Series II experiments were hospitalized patients without hematologic abnormalities or diseases known to influence the life span of erythrocytes. In preparation for these experiments, approximately $250 \mathrm{ml}$. of a $500 \mathrm{ml}$. ACD blood unit was tagged with $\mathrm{Cr}^{61}$ prior to storage. The tagged blood was stored at 4 to $6^{\circ} \mathrm{C}$. for periods specified in Table $\mathrm{I}$. The remainder of this unit was stored in the absence of chromium, and the red cells were tagged immediately prior to injection. Fifty ml. aliquots of each portion were transfused at weekly intervals, after the removal of 80 per cent of the plasma, and the resuspension of the cells in a sterile isotonic solution of sodium chloride containing $1 \mathrm{Gm}$. of dextrose per $100 \mathrm{ml}$.

As a precaution against bacterial infection of the recipient, stored blood was cultured aerobically and anaerobically at $5^{\circ}$ and $37^{\circ} \mathrm{C}$. on chopped meat, blood broth, and blood agar, and gram stained smears of the material were examined microscopically prior to injection.

Isoimmunization by transfused red cells was excluded by the observation of a negative Coomb's test, four to five months after transfusion, performed on fresh cells from the original donor following their incubation for one hour at $37^{\circ} \mathrm{C}$. with the serum of the recipient. 


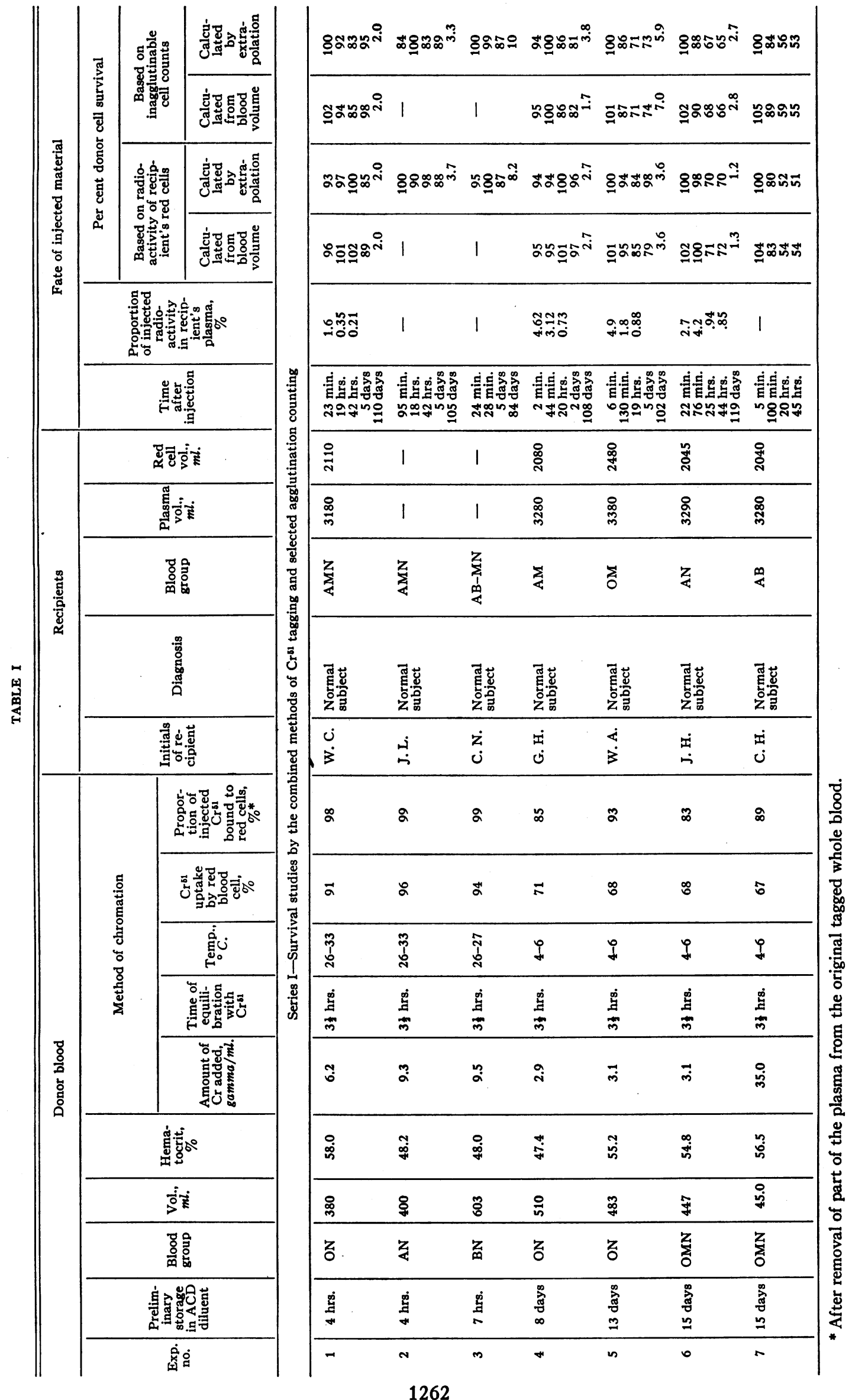




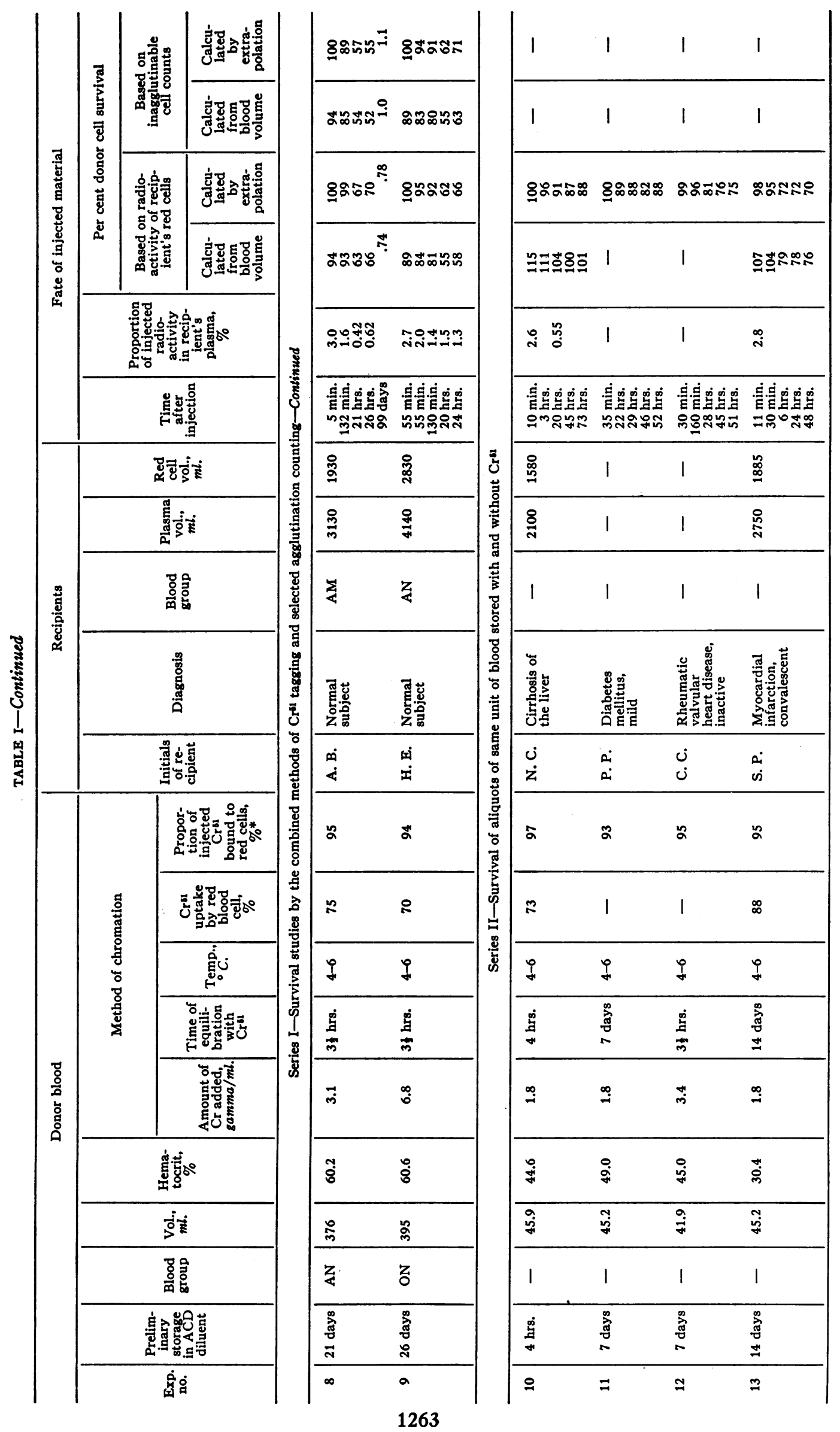




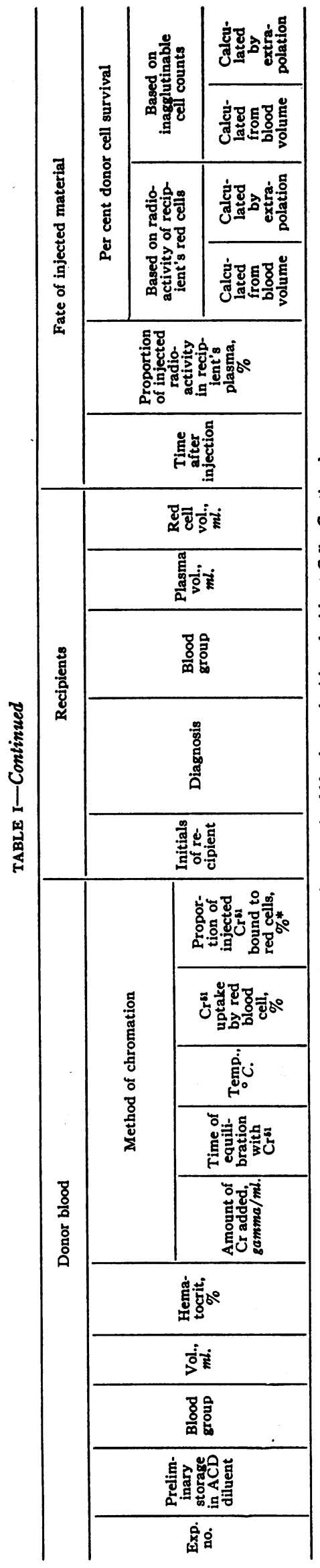

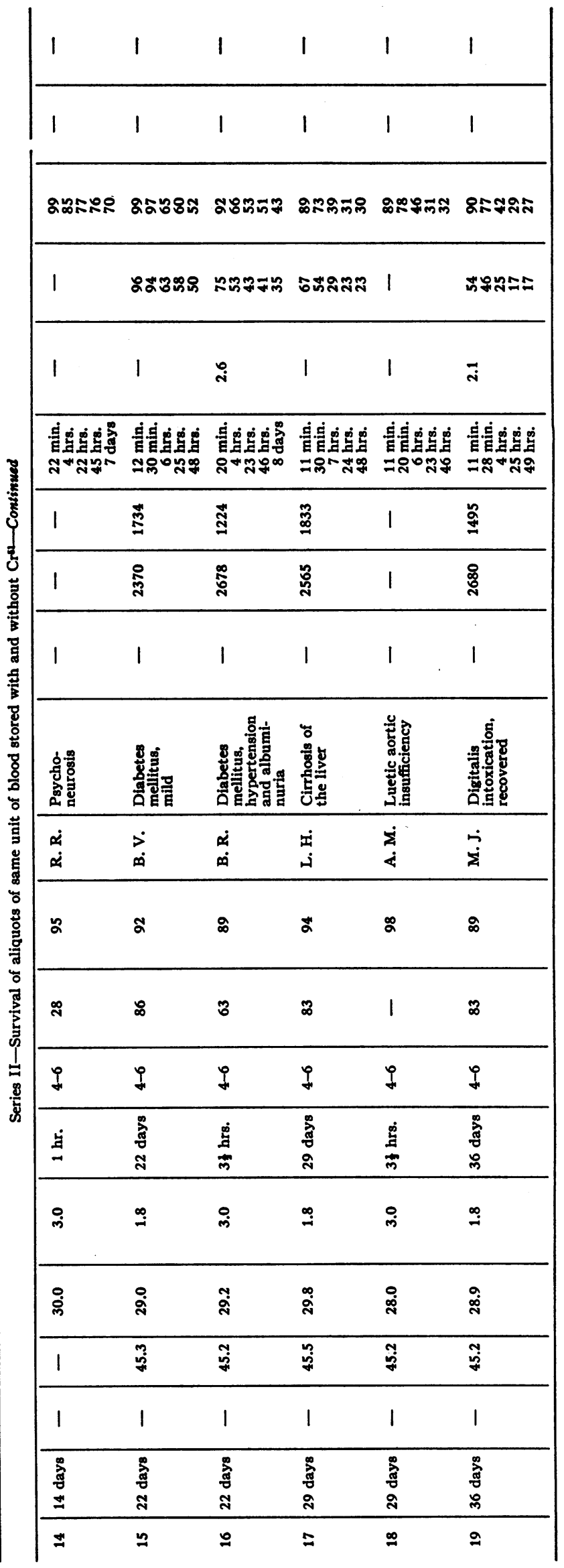




\section{Radioactivity measurement}

The gamma emission of chromium 51 , half life 27.5 days (11), was counted by a well-type scintillation counter,? having a gamma counting efficiency of approximately 37 per cent. Counts were performed on 3 to $4 \mathrm{ml}$. aliquots of whole blood contained in glass test tubes (O. D. $15 \mathrm{~mm}$., or in $4 \mathrm{ml}$. Gibson hematocrit tubes).8 When test tubes were used, the contents were always adjusted to the same volume for any series of bloods from the same recipient by the addition of saline solution; Gibson tubes were centrifuged at $3000 \mathrm{rpm}$. for one hour and, after removal of the plasma, placed in the scintillation counter well. Variations in geometry due to differences in the height of the red cell column in these specimens were compensated for by means of a correction factor applied to the observed counts. This factor was based on the empirical observation that the counting rate decreased 1.25 per cent for each unit of hematocrit increase between 25 and 53 per cent. The number of counts measured in these samples varied from 8000 to 25,600 . The background ranged from 100 to 116 counts per minute. Sufficient sample and background counts were measured to assure a standard deviation of 2 per cent or less for all but the weakest samples (Table II). A suitable chromium standard was counted every third or fouth sample tested, all counts being corrected for physical decay of $\mathrm{Cr}^{\text {b1 }}$ and for variations in the characteristics of the scintillation counter (which were negligible) by reference to this $\mathrm{Cr}^{\mathrm{s1}}$ standard.

The percentage of $\mathrm{Cr}^{51}$ taken up by red cells in vitro was determined as follows:

Aliquot portions of whole blood-sodium chromate mixtures, 0.1 to $0.2 \mathrm{ml}$. in volume, were placed in six test tubes. Three samples were diluted immediately with 10 ml. of isotonic saline, then centrifuged as quickly as pos-

TABLE II

Comparison of the theoretical counting errors of the selective agglutination and $\mathrm{Cr}^{51}$ methods*

\begin{tabular}{ccc}
\hline \hline & \multicolumn{2}{c}{ Percentage donor cells surviving destruction } \\
\cline { 2 - 3 } $\begin{array}{c}\text { Days after } \\
\text { transfusion }\end{array}$ & $\begin{array}{c}\text { Selective } \\
\text { agglutination }\end{array}$ & Cr's1 counting \\
\hline 0 & $100 \pm 12$ & $100 \quad \pm 4.0$ \\
30 & $64 \pm \pm 7.7$ & $57 \pm \pm 2.3$ \\
86 & $14 \pm \pm 2.2$ & $8.0 \pm 0.32$ \\
103 & $4.0 \pm 1.2$ & $3.0 \pm 0.24$ \\
\end{tabular}

* These figures represent errors resulting solely from random distribution, their magnitude depending upon the number of units counted and the ratio of the numerical value of the sample to that of the blank or background. The standard deviation is expressed as per cent of the original number of donor cells surviving destruction on the day indicated. The standard deviation expressed as per cent of donor cells present on a given day would be 12 per cent and 4 per cent for the selective agglutination technic and $\mathrm{Cr}^{51}$ technic, respectively, on day 0 and 28 per cent and 8 per cent, respectively, 103 days after transfusion.

' Sodium iodine thallium activated crystal in an Atomic Instrument Company scintillation head.

8 Macalaster Bicknell Company, Boston, Massachusetts. sible in order to prevent further $\mathrm{Cr}^{\mathrm{m}}$ uptake. The red cell sediment in these tubes was washed three times and suspended in isotonic saline solution. The radioactivity in each tube was measured and the percentage uptake of chromium by the red cells calculated by dividing the radioactive count in each sample of washed erythrocytes by the total number of counts in an aliquot mixture of whole blood and chromium, and multiplying the resulting value by 100 . The concentration of $\mathrm{Cr}^{\mathrm{m}}$ in the red cells of the recipient was obtained by dividing the number of counts observed in each sample by its volume, expressed as $\mathrm{ml}$., and by its hematocrit reading. The hematocrit readings were not corrected for amount of "trapped" plasma for reasons detailed below.

\section{Blood volume measurement}

The plasma volume of each recipient was determined by the T-1824 dye dilution technique (12). The total circulating red cell mass was calculated on the basis of the plasma volume and venous hematocrit, the latter having been modified by the correction factor 0.9 to correct for plasma occluded in the packed cell mass or for inequalities between the hematocrit of large and small vessels or for a combination of both.

(1) red cell volume (ml.)

$$
\begin{aligned}
& =\frac{\text { plasma volume }(\mathrm{ml} .)}{100-0.9 \times \text { venous hematocrit }(\%)} \\
& \quad \times 100-\text { plasma volume }(\mathrm{ml} .)
\end{aligned}
$$

In the first series of experiments red cell volume was determined in this manner two to three months following transfusion; in Series II, this was done at the time of injection of $\mathrm{Cr}^{61}$ tagged cells.

\section{Calculation of post-transfusion survival of chromium- labelled erythrocytes}

The percentage survival of transfused $\mathrm{Cr}^{\text {sin }}$ labelled cells in the recipient's circulating blood at any time after the transfusion was calculated from the following formula:

(2) Percentage donor cell survival

Radioactive $\mathrm{Cr}^{\mathrm{bl}}$ per $\mathrm{ml}$. of recipient's packed red $=\frac{\text { blood cells } \times \text { recipient's total red cell mass }}{\text { Total erythrocyte } \mathrm{Cr}^{51} \text { transfused }{ }^{9}}$

The concentration of $\mathrm{Cr}^{\mathrm{s1}}$ per $\mathrm{ml}$. of the recipient's packed red blood cells (the "specific activity of the red cells") was calculated by dividing the radioactivity per $\mathrm{ml}$. of whole blood by the uncorrected centrifuge venous hematocrit value as stated above. No correction factor for "trapped" plasma in the cell mass was applied to this hematocrit value because of disagreement on the part of the authors as to the magnitude of this factor $(13,14)$. If the hematocrit value had been modified by such a factor, the specific activity of the red cells and hence the percentage survival would have been higher than the values reported in this study, the difference being equal to the value of the correction factor applied.

9 Note : this value does not include the small amount of free $\mathrm{Cr}^{\mathrm{s1}}$ which was present in the injected plasma. 
This method of calculating percentage survival is based exclusively upon measured values, i.e., the total radioactivity of the tagged donor cells, the blood volume of the recipient, and the actual concentration of transfused cells per unit volume of the recipient's blood. (See Table I.)

\section{Inagglutinable cell counts}

Red cell counts were performed on cell suspensions prepared by diluting $0.1 \mathrm{ml}$. samples of whole blood with $20 \mathrm{ml}$. of isotonic saline solution. A 0.1 to $0.2 \mathrm{ml}$. aliquot sample of each suspension was placed in a 12 by $75 \mathrm{~mm}$. test tube containing approximately $10 \mathrm{mg}$. of dried anti-A or $M$ serum ${ }^{10}$ (15). A second aliquot sample was placed in a hemocytometer chamber, and the total red cell concentration determined on the basis of a count of 1000 cells or more. The test tubes containing the cell suspension and dissolved antisera were centrifuged at $900 \mathrm{rpm}$. for one minute, after which the cell sediment was resuspended by tapping the tube vigorously 30 to 50 times. An aliquot portion of this suspension containing a mixture of agglutinated and inagglutinated cells was then transferred to a counting chamber and the free, inagglutinated cells counted. In each instance the minimum number of inagglutinated cells counted was 200 , or the number present in $18 \mathrm{~mm}^{2}$ of counting area when the number in this area was less than 200. Prior to each transfusion, a blank inagglutinable cell count was performed on the recipient cell suspension containing an aliquot portion of the anti-serum reserved for that particular study. The ratio of the number of inagglutinable cells minus the blank count to the total cell count multiplied by 100 was expressed as per cent donor cells. The field error in the selective agglutination counts reported in this series varied from a S. D. \pm 6 to S. D. \pm 15 per cent (Table II). Calculations of percentage of survival of donor cells counted by the selective agglutination method were based on T-1824 blood volume data, as in the case of the $\mathrm{Cr}^{51}$ tagged cells.

\section{EXPERIMENTAL OBSERVATIONS}

\section{Chromation of Erythrocytes in Vitro}

\section{Influence of temperature and $p H$}

The rate at which chromium combined with red cells when sodium chromate was added to whole ACD blood was dependent upon the temperature and $\mathrm{pH}$ of the mixture, as demonstrated in Figure 1 and Table III. At $39^{\circ}$ C., 90 per cent of available chromium was incorporated in the erythrocytes within a period of five minutes, as compared to a 50 to 75 per cent uptake at $26^{\circ} \mathrm{C}$. and 10 to 20 per cent at $1.8^{\circ} \mathrm{C}$. After thirty minutes of equilibration the proportions taken up at $26^{\circ}$ and

\footnotetext{
10 Powdered grouping serum, Lederle Laboratories, Pearl River, New York.
}

$39^{\circ} \mathrm{C}$. were comparable, i.e., approximately 90 per cent. The influence of $\mathrm{pH}$ on the kinetics of this reaction is apparent from the observation that the chromium uptake at $\mathrm{pH} 6.0$ was three to four times as rapid as at $\mathrm{pH} 7.3$ (Table III).

\section{Influence of storage, concentration of $\mathrm{Na}_{2} \mathrm{Cr}^{51} \mathrm{O}_{4}$, and stability of the Cris-erythrocyte union in vitro}

Preliminary storage of erythrocytes at $4^{\circ}$ to $6^{\circ} \mathrm{C}$. for periods as long as twenty-nine days did not appear to reduce their affinity for chromium. On the contrary, $\mathrm{Cr}^{51}$ uptake was more rapid in stored than in fresh blood, due perhaps to the greater acidity of the former. The $\mathrm{pH}$ of whole ACD blood immediately after collection is approximately 7.2 ; after storage for one week at $4^{\circ}$ to $6^{\circ}$ C. the expected $\mathrm{pH}$ value is approximately 7.0 , falling to 6.8 after two weeks, and 6.6 to 6.7 after three weeks or longer. Chromium uptake, expressed in terms of the percentage bound by red cells following the addition of $\mathrm{Na}_{2} \mathrm{Cr}^{51} \mathrm{O}_{4}$, was not influenced by variations in concentration ranging from 0.25 to 9.5 micrograms of chromium salt (expressed in terms of chromium metal content) per ml. of whole blood (Table I, Figure 1). The erythrocyte-chromium bond remained stable during storage in ACD plasma, inasmuch as there was no elution of $\mathrm{Cr}^{51}$ from tagged erythrocytes stored as long as thirty-six days (Table I, Experiments $10,13,17$, and 19).

\section{Does $C r^{51}$ released from hemolyzed cells relabel the recipient's red cells?}

The extent to which $\mathrm{Cr}^{51}$ from hemolyzed red cells may combine with intact erythrocytes in vitro was investigated as follows :

Radioactive sodium chromate was added to whole ACD blood in a concentration of 2.5 micrograms per ml., and the mixture, divided into three aliquot samples, was allowed to stand for ninety minutes at $1.8^{\circ}, 26.6^{\circ}$, and $39^{\circ} \mathrm{C}$. The red cells in each sample, which had taken up 40, 84, and 92 per cent of available chromium, respectively, were washed three times in saline solution and then subjected to repeated freezing and thawing until hemolysis was complete. Each hemolysate was mixed with an equal volume of washed, intact erythrocytes and incubated for ninety minutes at 


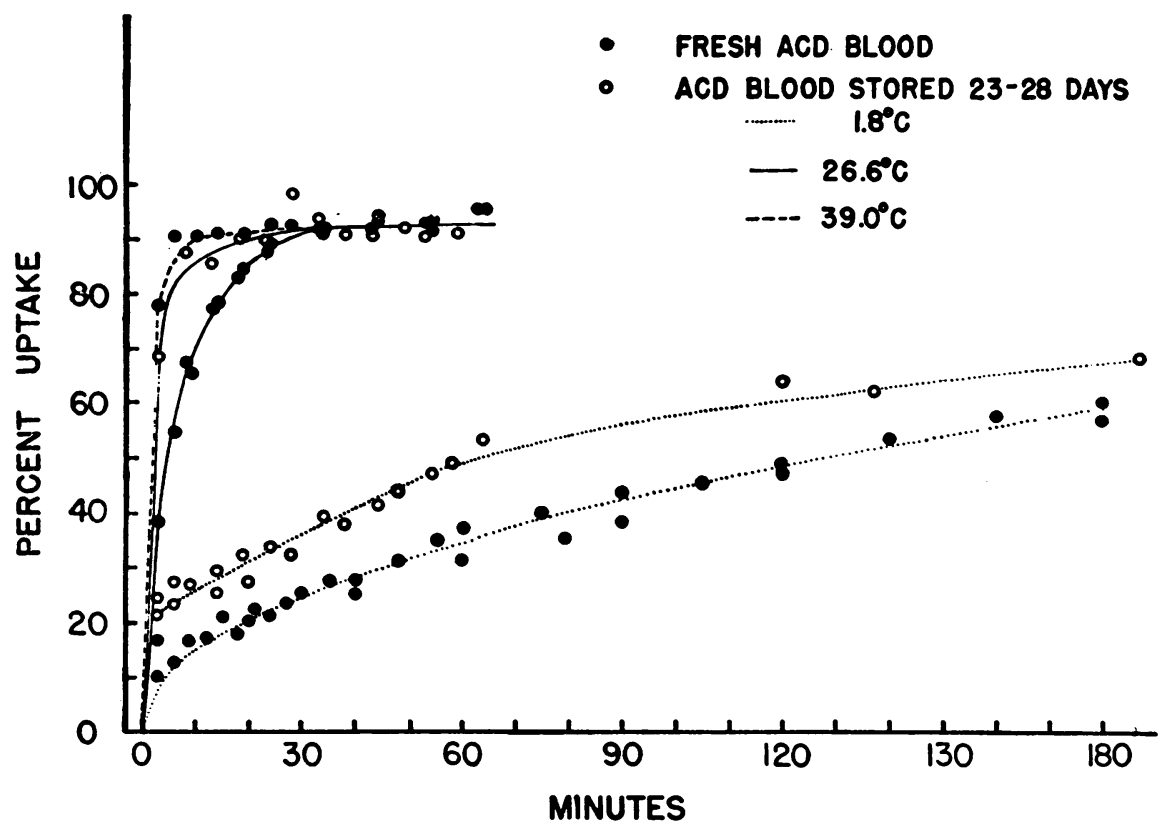

Fig. 1. The Rate of Sodium Chromate Uptake by Fresh and Aged ACD Blood at Different Temperatures

The $\mathrm{pH}$ of the stored blood was between 6.7 and 6.8. The $\mathrm{pH}$ of the fresh blood was 7.1 to 7.2. The concentration of $\mathrm{Na}_{2} \mathrm{Cr}^{51} \mathrm{O}$ ( (expressed in terms of chromium metal content) was 2.5 gamma per ml. in all bloods except one of the two fresh bloods studied at $26^{\circ} \mathrm{C}$. which was 0.25 gamma per $\mathrm{ml}$.

the same temperature to which the hemolyzed cells had originally been exposed. Finally, the intact cells were separated, washed, and tested for $\mathrm{Cr}^{51}$ uptake, which was discovered to be negligible in all samples (i.e., less than 0.5 per cent). The in vitro observations were substantiated by the following in vivo experiment: Tagged erythrocytes were washed three times in saline and lysed by the addition of ten volumes of distilled water. The hemolysate was then made isotomic by the addi-

TABLE III

Effect of pH on the rate of Cr51 uptake by aliquot samples of fresh erythrocytes in whole $A C D$ blood at $2^{\circ} C .^{*}$

The concentration of $\mathrm{Na}_{2} \mathrm{Cr}^{51} \mathrm{O}_{4}$ was 2.5 gamma per ml. whole blood

\begin{tabular}{ccc}
\hline \hline & \multicolumn{2}{c}{ Per cent $\mathrm{Cr}^{\text {b1 }}$ uptake by erythrocytes } \\
\cline { 2 - 3 } $\mathrm{pH}$ & $\begin{array}{c}\text { After } 3 \text { min. } \\
\text { equilibration }\end{array}$ & $\begin{array}{c}\text { After 15 min. } \\
\text { equilibration }\end{array}$ \\
\hline & $\%$ & $\%$ \\
7.3 & 8 & 11 \\
6.9 & 11 & 12 \\
6.0 & 28 & 41
\end{tabular}

* Effect of pH on the rate of $\mathrm{Cr}^{51}$ uptake by red cells at $2^{\circ} \mathrm{C}$. after addition of 2.5 gamma of chromium (as $\mathrm{Na}_{2} \mathrm{Cr}^{51} \mathrm{O}_{4}$ ) per ml. of fresh whole ACD blood. tion of $\mathrm{NaCl}$ and passed through a Berkefeld filter and injected back into the original donor of the red cells. During the first twenty-four hours 27 per cent of the injected dose was excreted in the urine. None of the injected $\mathrm{Cr}^{51}$ was fixed to, nor reappeared in, the recipient's cells during the thirty-day observation period following the injection.

\section{Survival of chromated erythrocytes in vivo}

The survival of $\mathrm{Cr}^{51}$-labelled donor erythrocytes has been observed in 19 subjects based on the radioactivity of the recipient's blood after transfusion. The results of these studies, in part, are presented in Table I, together with data pertaining to the preliminary processing, storage, and chromation of injected cells. Nine recipients were studied by the combined application of the chromium labelling and selective agglutination counting methods, the results of which are likewise included in Table I (Experiments 1 to 9), and represented in graphic form in Figure 2. The survival in five recipients of transfused donor cells from the same half unit 

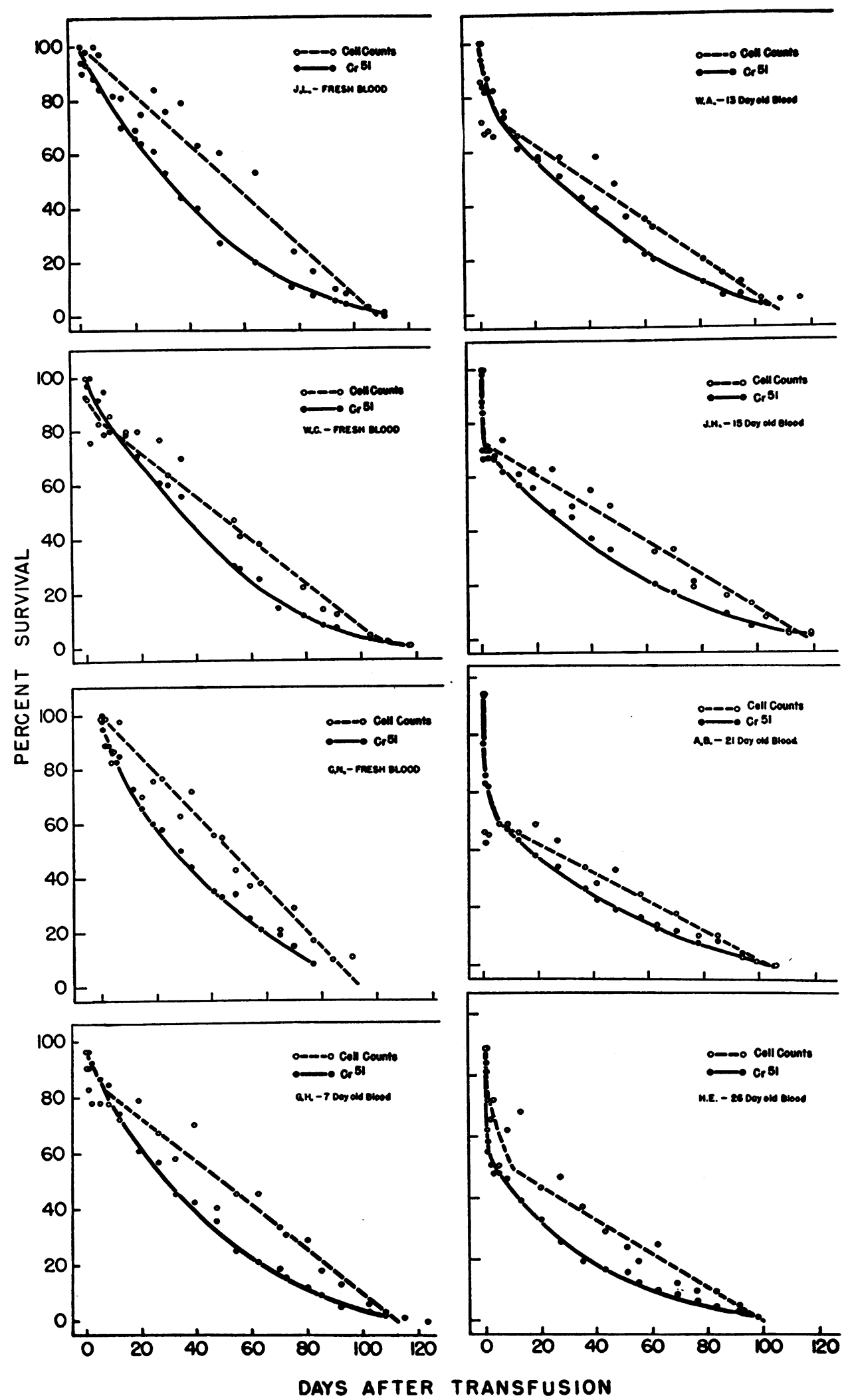

Fig. 2. Comparison of Red Cell Survital Data Obtained by Selective Aggutination and $\mathrm{Cr}^{\mathrm{m}}$ Counting 
of donor blood, stored with $\mathrm{Na}_{2} \mathrm{Cr}^{51} \mathrm{O}_{4}$ for periods varying from one to five weeks, is shown in Table $I$ and Figure 5. As a control on the effect of storing red cells with $\mathrm{Na}_{2} \mathrm{Cr}^{51} \mathrm{O}_{4}$, the survival of aliquot portions from the other half of the same unit of blood which were tagged just before their transfusion is shown in Table I (Experiments 10, 12, 14, 16, and 18) and Figure 5.

Comparison of red cell survival as measured simultaneously by the chromium technique and selective agglutination

The survival of $\mathrm{Cr}^{51}$-labelled erythrocytes measured in the same recipient both by radioactive and selective agglutination counting is represented by the paired curves in Figure 2, constructed from data obtained by both techniques on twenty or more occasions over a period of 100 to 130 days following each transfusion of $\mathrm{Cr}^{51}$-labelled red cells. Donor cell survival as measured by the $\mathrm{Cr}^{51}$ method is represented by a complex curve which is neither logarithmic nor linear, and the end point of which coincides with the total disappearance of inagglutinable cells.

Comparison of data obtained by selective agglutination and $\mathrm{Cr}^{51}$ counting during the first two days (Figure 3) indicates that the former values are consistently higher during the first fortyeight hour period following transfusion, the degree of difference averaging 6.7 per cent. The probability that this difference was due to chance is less than 0.01 per cent. The discrepancy may be due to a systematic error in the $\mathrm{Cr}^{51}$ and in selective agglutination cell survival data. It is unlikely that it is due to tagging of the recipient's erythrocytes by the small amount of injected unbound $\mathrm{Na}_{2} \mathrm{Cr}^{51} \mathrm{O}_{4}$ (average of 6.5 per cent of the total injected radioactivity for Experiments 1 to 9 , Table I) since only about 10 per cent of free $\mathrm{Na}_{2} \mathrm{Cr}^{51} \mathrm{O}_{4}$ when injected intravenously tags recipient erythrocytes as was demonstrated in three experiments of which the following experiment is an example:

A solution of sodium chromate containing a total of $0.8 \mathrm{mg}$. of $\mathrm{Na}_{2} \mathrm{Cr}^{51} \mathrm{O}_{4}$ expressed in terms of its chromium metal content was added to $100 \mathrm{ml}$. of saline and the mixture injected intravenously. Five minutes following injection 12 per cent of the injected $\mathrm{Cr}^{51}$ was bound to the erythrocytes and remained fixed at that level in the erythrocytes

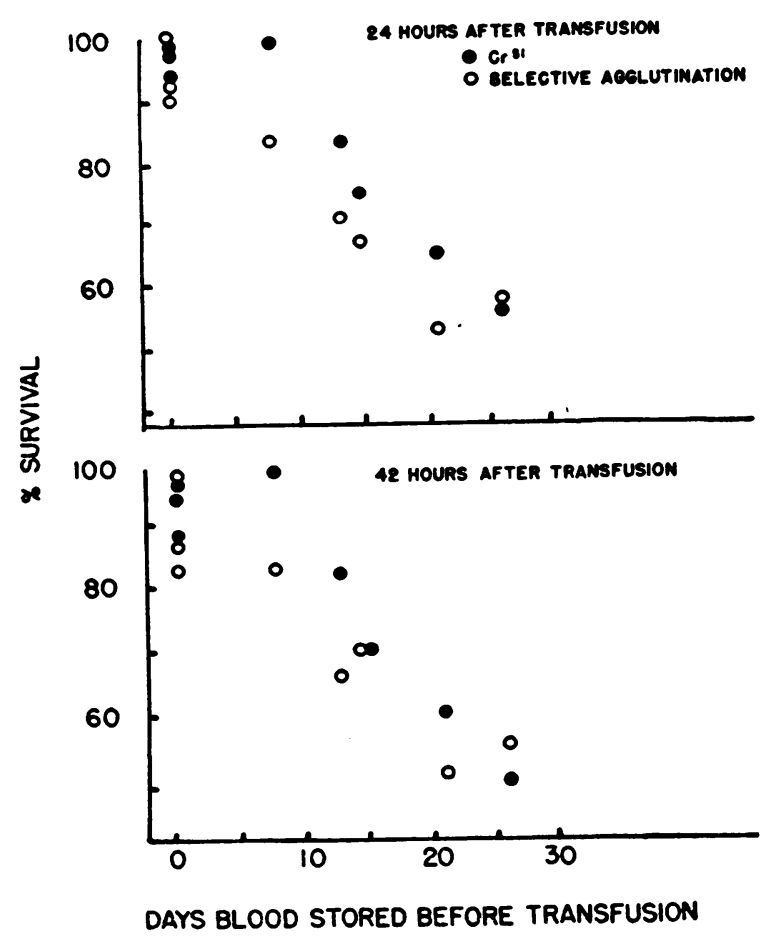

Fig. 3. Comparison of Selective Agglutination and Cr $^{\text {min }}$ Counts as a Measure of Survival on the Same Unit of Blood 24 and 42 Hours after Transfusion

for a period of at least one week, after which a gradual decline in chromium concentration occurred. It may be pointed out that the amount of chromium injected in this experiment was greater than the largest amount of unbound chromium injected in the transfusion experiments described in this report.

All $\mathrm{Cr}^{51}$ values obtained one week or more following transfusion are consistently lower than the corresponding values obtained by selective agglutination counts (Figure 2). The difference between these two curves might be explained either on the basis of a continuous chromium elution from the circulating labelled cells or on the assumption that the amount of chromium taken up by the donor cells is not the same for each cell, but in direct proportion to the age of the red cell at the time of collection from the recipient, i.e., the senescent cells binding the most $\mathrm{Cr}^{51}$, and the young cells the least. There is no experimental data for or against either hypothesis at present. However, for purposes of discussion, the progressive decline in the concentration of $\mathrm{Cr}^{51}$ in circulating donor cells will be characterized as an elution phenome- 
non. The rate of $\mathrm{Cr}^{51}$ loss from intact donor cells (i.e., biologic decay), as distinguished from loss of the $\mathrm{Cr}^{51}$ attributable to the hemolysis of tagged cells, may be calculated on the basis of changes in the ratio of cell survival determined by $\mathrm{Cr}^{51}$ counts and the corresponding values based on selective agglutination counts. A semilogarithmic plot of the per cent of original amount of $\mathrm{Cr}^{51}$ remaining on the donor cells for the transfusion experiments (Figure 4), indicates that the biologic half-life of red cell bound $\mathrm{Cr}^{51}$ may range from fifty-one to ninety days (Table IV). Excluding Experiment 9 from these calculations, the results of which vary more than two standard deviations from the mean of all the data, the mean half-life of chromium elution is $77 \pm 12$. Survival of transfused erythrocytes can be accurately measured during the first two days after transfusion without corrections for this loss of $\mathrm{Cr}^{51}$ since less than 3 per cent of transfused donor cell $\mathrm{Cr}^{51}$ is eluted from the red cells during this interval. Long-term survival values based on $\mathrm{Cr}^{51}$ determinations are subject to error unless the phenomenon of chromium elution is taken into account and a correction fac- tor introduced to compensate for its effect. Such a correction factor may be based on the observed half-life of chromium elution, or biological decay of $\mathrm{Cr}^{51}$. For example, 66 per cent of injected cellcount $\mathrm{Cr}^{51}$ is present in the recipient (Experiment 2, Table I, and Figure 2) on the twentieth day and 53 per cent on the thirtieth day following transfusion; the average rate of donor cell hemolysis throughout the ten-day period, based on uncorrected data, would be $(66-53) / 10$ or 1.3 per cent per day for the ten-day period. However, only 83 per cent of the original amount of $\mathrm{Cr}^{51}$ present in the transfused cells remains twenty days after transfusion and 76 per cent thirty days after transfusion. Correcting for this "elution" of $\mathrm{Cr}^{51}$ by use of the above figures, the hemolytic rate would then equal $(80-70) / 10$ or $1.0 \pm 0.15$ per cent as calculated from the $\mathrm{Cr}^{51}$ data in contrast to the observed hemolytic rate of 0.9 per cent per day as determined by selective agglutination counting for the same recipient during the same interval of time. A large part of the discrepancy between the two methods is due to the variation in $\mathrm{Cr}^{51}$ elutions observed in donor blood thus far studied.

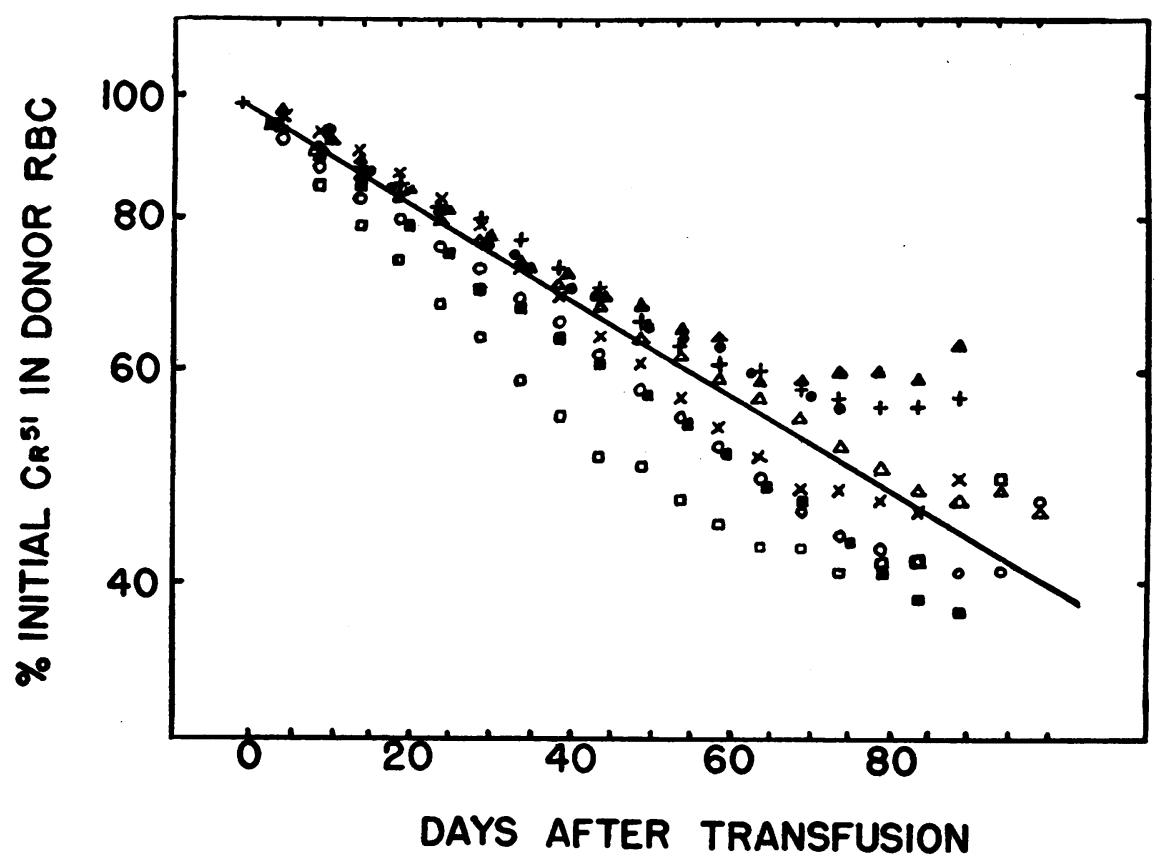

Fig. 4. The Rate of $C_{R}^{\text {on }}$ Elution from Transfused $C_{R}^{m}$ Labelled ERythrocytes

The ordinate scale is logarithmic and indicates the percentage of original $\mathrm{Cr}^{\mathrm{s1}}$ present in the circulating red cells for any given day (abscissa) after transfusion. The individual experiments are identified by the following symbols: Exp. $1-X ;$ Exp. $2-0$;

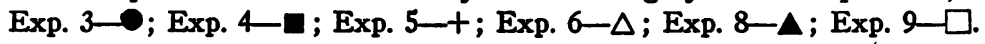




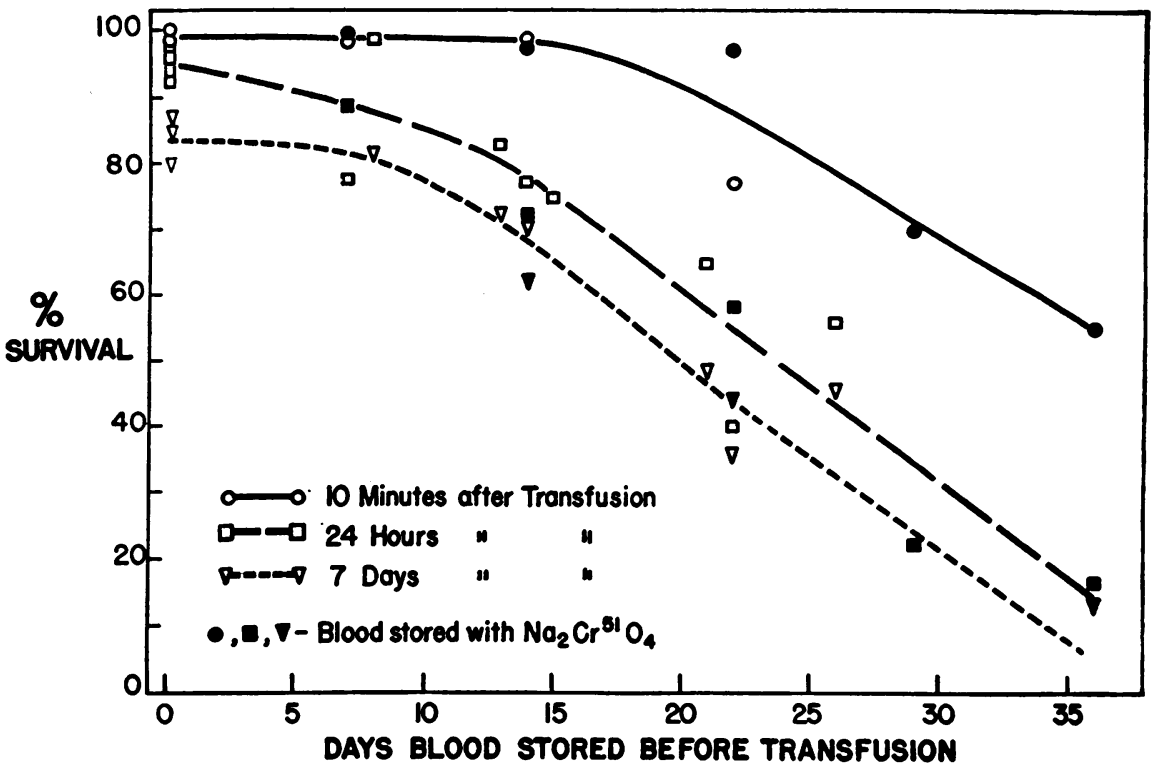

Fig. 5. The Survival of Red Cells as Measured by Counting $\mathrm{CR}^{61}$ Ten Minutes, Twenty-four Hours, and One Week after Transfusion

The closed symbols represent blood stored with $\mathrm{Na}_{2} \mathrm{Cr}^{51} \mathrm{O}_{4}$, the open symbols blood stored without $\mathrm{Na}_{2} \mathrm{Cr}^{\mathrm{s}_{1}} \mathrm{O}_{4}$.

\section{The Effect of Chromation on Red Cell Survival}

The maximum red cell survival of fresh ACD blood is commonly stated to be approximately 120 days. Inspection of the curves in Figure 2 based on selective agglutination counts indicates that the extinction point of $\mathrm{Cr}^{51}$ counts following transfusion of blood previously stored 0 to 8 days range from 108 to 115 days. The sole exception was found in Experiment 3 in which the end point occurred at ninety-four days. Inasmuch as the subject of this experiment had previously received three experimental transfusions, it may be specu-

TABLE IV

Rate of chromium 51 elution from circulating donor erythrocytes

\begin{tabular}{ccc}
\hline \hline $\begin{array}{c}\text { Experi- } \\
\text { ment }\end{array}$ & $\begin{array}{c}\text { Preliminary } \\
\text { storage of } \\
\text { donor blood }\end{array}$ & $\begin{array}{c}\text { Half-life of } \\
\text { chromium in } \\
\text { red cells } \\
\text { days }\end{array}$ \\
\hline 1 & 4 hrs. & 64 \\
2 & 4 hrs. & 65 \\
3 & 7 hrs. & 90 \\
4 & 8 days & 65 \\
5 & 13 days & 87 \\
6 & 15 days & 82 \\
8 & 21 days & 87 \\
9 & 26 days \\
& Mean \pm S.D. & $74 \pm 33$ days \\
& Mean (excluding Exp. 9) \pm S.D. & $77 \pm 12$ days \\
\hline
\end{tabular}

lated that the relatively brief survival period observed in this study may have been attributable to isoimmunization with the production of isoantibodies of an obscure variety or so weak as to escape detection by the indirect Coomb's test. Also, the donor blood used in this experiment was washed twice in isotonic saline before injection, a procedure which may conceivably have damaged the erythrocytes.

\section{Effect of erythrocyte storage with $\mathrm{Na}_{2} \mathrm{Cr}^{51} \mathrm{O}_{4}$ on survival}

The effect on red cells of prolonged exposure to chromium, as evidenced by their post-transfusion survival, was studied in Experiments 10 to 19 (Table I), which were conducted as follows:

Two equal portions of fresh ACD blood from the same unit of blood were placed in separate containers. To one of these was added $\mathrm{Na}_{2} \mathrm{Cr}^{51} \mathrm{O}_{4}$. Both portions were placed in storage. At weekly intervals, $50 \mathrm{ml}$. samples from each portion were removed and transfused, the portion which had been stored without chromium having been tagged immediately before injection. Comparison of the survival of blood stored with and without chromium (Figure 5) indicates that the portion ex- 
posed to chromium continuously throughout storage was entirely comparable to the control samples labelled immediately before transfusion.

\section{Effect of red cell exposure to high concentrations of $\mathrm{Na}_{2} \mathrm{Cr}^{51} \mathrm{O}_{4}$}

Exposure of red blood cells to sodium chromate within the concentration range of 1.8 to 9.5 micrograms per ml. of whole blood (expressed as elemental chromium) in four fresh blood samples had no apparent influence on immediate post-transfusion survival (Table I, Figure 2, Figure 5).

In order to determine the effect of relatively high concentrations of chromium on red cell longevity, an experiment was performed involving the transfusion of two aliquot samples from the same unit of donor blood which had previously been stored at 4 to $6^{\circ} \mathrm{C}$. for fourteen days, then labelled with $\mathrm{Na}_{2} \mathrm{Cr}^{51} \mathrm{O}_{4}$. The proportions of blood and sodium chromate were such that the concentrations of chromium metal in the two samples differed by a factor of 10 , i.e., 3.1 micrograms as compared to 35 micrograms of chromium metal per $\mathrm{ml}$. of whole donor blood. Inspection of the curves representing the survival of these two portions (Figure 6) indicates that within twenty-four

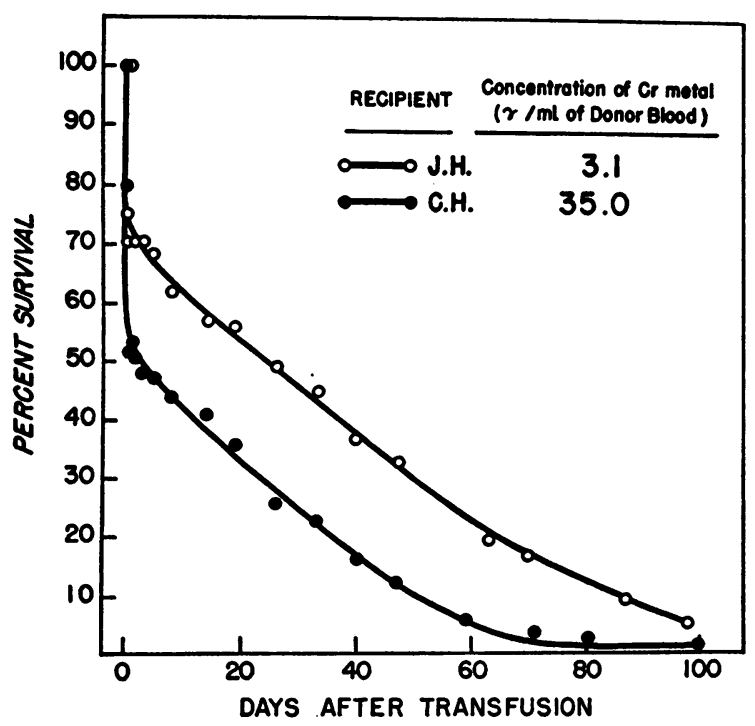

Fig. 6. Comparison of the Survival, as Measured by Counting $C_{R}{ }^{b 1}$, of Two Aliquots of the Same Donor Blood, One of Which Was Tagged with a Concentration of 35 Gamma, and the Other 3.1 Gamma of $\mathrm{NA}_{2} \mathrm{CR}^{\text {s1 }} \mathrm{O}_{4}$ (IN Terms of Chromium Metal Per ML. OF WHOLE BLOOD) hours following transfusion 50 per cent of the heavily tagged blood was eliminated, in contrast to 30 per cent destruction in the case of the lightly exposed cells. The results of this single experiment are by no means conclusive, in view of the fact that these observations were made in different recipients, but suggest that exposure to chromium in a concentration of 35 micrograms per $\mathrm{ml}$. of whole blood may have resulted in cell damage evidenced by an increase in the proportion destroyed immediately following injection. Throughout the remainder of their life span, both the cells which had been exposed to the high concentration and those which were exposed to the low concentration of chromium were eliminated at rates that were equal to those observed for unlabelled donor blood stored in ACD plasma for the same period of time.

\section{Excretion of $\mathrm{Cr}^{51}$}

The excretion of $\mathrm{Cr}^{51}$ in the urine at various intervals after transfusion is shown in Table V. The data indicate that for long periods of time after the transfusion at least a quarter of the amount of $\mathrm{Cr}^{51}$ known to have been removed from the circulation is excreted in the urine. Exceptions occurred during the period of rapid hemolysis in the case of Experiments 9 and 15, where only 8.5 per cent and 17 per cent, respectively, of the amount disappearing from the circulation during the first twenty-four and forty-eight hours appeared in the urine. Preliminary observations in dogs show that during the interval of 0 to 7 days after a

TABLE V

Urinary excretion of chromium 51 compared to the amount disappearing concomitantly from the circulation in eight transfusion recipients

\begin{tabular}{|c|c|c|c|c|}
\hline $\begin{array}{c}\text { Experi- } \\
\text { ment } \\
\text { no. }\end{array}$ & $\begin{array}{c}\text { Days } \\
\text { after } \\
\text { trans- } \\
\text { fusion }\end{array}$ & $\begin{array}{c}\text { Per cent of } \\
\text { total injected } \\
\text { dose of Crbs } \\
\text { disappearing } \\
\text { from circu- } \\
\text { lating blood } \\
\text { during this } \\
\text { period }\end{array}$ & $\begin{array}{l}\text { Per cent } \\
\text { of Crst } \\
\text { disappearing } \\
\text { from the } \\
\text { circulation } \\
\text { excreted } \\
\text { in the } \\
\text { urine }\end{array}$ & $\begin{array}{l}\text { Per cent of } \\
\text { total Cr } 51 \\
\text { excreted } \\
\text { in urine }\end{array}$ \\
\hline $\begin{array}{r}10 \\
8 \\
15 \\
9 \\
8 \\
4 \\
6 \\
7 \\
1\end{array}$ & $\begin{array}{c}0-2 \\
0-1 \\
0-1 \\
0-2 \\
12-13 \\
28-29 \\
30-31 \\
30-31 \\
57-58\end{array}$ & $\begin{array}{l}11.0 \\
29 \\
46 \\
64 \\
1.07 \\
0.97 \\
0.70 \\
0.84 \\
0.72\end{array}$ & $\begin{array}{c}52 \\
45 \\
8.5 \\
17 \\
93 \\
102 \\
27 \\
24 \\
65\end{array}$ & $\begin{array}{c}5.7 \\
13.1 \\
3.9 \\
10.9 \\
0.99 \\
0.99 \\
0.19 \\
0.20 \\
0.47\end{array}$ \\
\hline
\end{tabular}


transfusion of poorly preserved blood, 85 per cent of which was removed from the circulation during the first week post-transfusion, 20 per cent of the injected dose was excreted in the urine and 7 per cent in the feces.

\section{DISCUSSION}

The experimental evidence herewith presented indicated that radioactive, chromium-labelled erythrocytes can be employed for evaluating the post-transfusion survival of red blood cells for periods of at least twenty-four to forty-eight hours after. transfusion and possibly for much longer periods of time, perhaps for their entire life span. The method is ideally suited for evaluating the effectiveness of in vitro erythrocyte preservation techniques, and possibly may prove to be of great value for studying the life span of erythrocytes in various disease states.

The considerations which are of paramount importance in establishing the validity and applicability of this method are the following:

(1) The capacity of erythrocytes to bind the chromate ion under certain conditions;

(2) The "firmness" or permanency of this binding ;

(3) The possibility that the labelling of erythrocytes with radioactive chromium adversely influences the survival of the cells in the recipient;

(4) The possibility that radioactive chromium liberated from transfused red cells (either by elution or from cellular destruction) may. re-enter and tag the recipient's own cells ;

(5) The question as to the safety of this method from the standpoint of radiation effects in human subjects receiving blood labelled with radioactive chromium.

\section{Erythrocyte-chromium union}

The union between erythrocytes and radioactive sodium chromate takes place in vitro regardless of the duration of time that the erythrocytes have been stored prior to their exposure to sodium chromate. This fact makes possible the labelling and subsequent post-transfusion study of blood which has been stored for prolonged pe- riods of time before injection. It is also apparent from our studies that the chromation of fresh blood and storage in the chromated state is in no way different from the standpoint of eventual post-transfusion survival than chromation of blood just prior to transfusion. These features make the method eminently satisfactory for a study of blood storage methods.

It is quite feasible to chromate erythrocytes at refrigeration temperatures without subjecting them to the possibly deleterious influence of incubation, since our studies show that erythrocytes will take up chromium at $4^{\circ} \mathrm{C}$. in quantities sufficient to allow transfusion studies. The rapidity and amount of chromium taken up by red cells increases with increase of temperature to $39^{\circ} \mathrm{C}$.

Chromation proceeds slightly more rapidly and to a somewhat greater degree at a $\mathrm{pH}$ of 6.0 than at a $\mathrm{pH}$ of 7.2, which is reflected in a greater uptake of chromium by blood stored for significant periods of time than by fresh blood, since the $\mathrm{pH}$ of stored blood is lower than that of fresh blood.

The percentage of sodium chromate bound to erythrocytes is not appreciably influenced by the amount of chromate ion present within the range of 0.25 to 10.0 micrograms of chromium ion per ml. of blood.

Our studies do not provide information as to the nature of the chromate-erythrocyte bondwhether it be simple physical adsorption, chemical linkage, or enzymatic binding.

The erythrocyte-chromate linkage appears to be quite stable, at least in vitro, inasmuch as repeated washings with saline removed negligible amounts of the labelling material. In vivo, however, there is a steady and apparently exponential disappearance of the radioactive chromium from the labelled erythrocytes, half of the chromium disappearing in $77 \pm 12$ days in our experiments. Such a disappearance might be explained either by a process of elution of the chromate ion from the erythrocyte, or by preferential rapid destruction of the chromated cells. The rather wide range of biologic half times may well be accounted for by the fact that the bloods on which these elution rates were determined had been processed in a variety of ways. It may be that freshly drawn and chromated bloods reinfused into a recipient may have a more nearly constant rate of elution. 


\section{Is there labelling of the recipient's erythrocytes by radioactive chromium liberated in vivo?}

This is a critical consideration from the standpoint of the validity of this method for evaluating long-term erythrocyte survival. Thus, if chromate ion which has escaped from intact erythrocytes or is released by hemolysis from senescent red cells were to re-enter and label the erythrocytes of the recipient, the rate of the disappearance from the circulating cell mass of the recipient could not be interpreted in terms of the survival of donor cell population.

Analysis of the cases in which as much as fifty per cent of the transfused, labelled cells were destroyed during the first twenty-four hours after transfusion revealed that survival, as measured simultaneously by selective agglutination and $\mathrm{Cr}^{51}$ methods, agreed closely following this period of rapid destruction. If retagging of the recipient's red cells had occurred under these circumstances, the survival as measured by $\mathrm{Cr}^{51}$ would have been significantly higher than that as determined by selective agglutination. The above observation does not exclude re-utilization of the injected $\mathrm{Cr}^{51}$ by the recipient's bone marrow and the gradual incorporation of $\mathrm{Cr}^{51}$ in recipient red cells. This possibility is excluded by the observation that after the injection of $\mathrm{Cr}^{51}$-tagged hemoglobin, none appeared in the recipient's red cells at any time during the following month.

Since from 1 to 17 per cent of the injected chromate was not bound to the donor cells employed in this study, but was present in the donor plasma, the possibility existed that recipient cells could have been tagged by this "free" chromate. Experiments have shown that no more than 12 per cent of the injected aqueous chromate is attached to the recipient's red cells. Thus, no more than 12 per cent of the total amount of injected $\mathrm{Cr}^{51}$ contained in the donor plasma could have become bound to the recipient's cells. This observation has practical as well as theoretical impartance, since it makes unnecessary the processing of blood with the aim of complete removal of the portion of added sodium chromate which does not become fixed to the red cells.

\section{The in vivo survival of chromated erythrocytes}

Careful determination of the survival of chromated erythrocytes by the Ashby differential agglutination method indicates that during the first twenty-four to forty-eight hours after transfusion, the behaviour of chromated cells is quite comparable to the survival which would be expected of non-chromated red cells. This is true of fresh bloods in which survival of the transfused cells is normal, and of bloods stored for prolonged periods of time in which there is initial rapid destruction of the donor cells. These findings establish the validity of the chromated cell method of evaluating the effectiveness of blood preservation methods, since it is the survival of donor cells in the immediate post-transfusion period which is of paramount importance in evaluating the viability of transfused erythrocytes.

The survival values of the bloods stored for prolonged periods of time in ACD medium as indicated by the chromated cell method are lower by some 10 per cent than the values previously reported as determined by the radio-iron tagged cell method (1-3). This discrepancy might be explained by the fact that the hematocrit value employed in calculating red cell survival in these studies was not modified by a correction factor as was done in the studies on survival of radio-iron tagged cells. It might also reflect a deleterious influence of sodium chromate on the erythrocytes. The concentration of chromium which is definitely injurious to erythrocytes has not been determined in this study. Suggestive evidence was obtained which indicated that a concentration of 35 micrograms of sodium chromate (expressed as elemental chromium) per ml. of whole blood did shorten the immediate post-transfusion survival of the labelled erythrocytes. On the other hand, variations in concentrations of chromium from 1.8 to 9.5 micrograms per $\mathrm{ml}$. of whole blood did not have any detectible influence on post-transfusion survival of labelled erythrocytes. Until more data are obtained on the upper limits of chromium concentration not toxic to erythrocytes, it is suggested that future survival studies of chromium-labelled erythrocytes be performed on blood exposed to concentrations of chromium of one microgram or less per $\mathrm{ml}$. of whole blood. The specific activity of radioactive sodium chro- 
mate currently available is of sufficient magnitude to allow satisfactory red blood cell survival experiments to be conducted at this level of chromium concentration. Survival of chromated cells over prolonged periods after transfusion appears to be somewhat less than the customarily accepted mean survival time of 120 days. It is possible that further studies may show that these particular observed values may be within the normal biologic range of erythrocyte survival. If this shortening of survival by 10 per cent is found to be constant, however, it should not invalidate the possible value of long-term survival studies in which relatively large changes in rates of erythrocyte destruction are in question (e.g., in acquired hemolytic anemia, or during induced hemolytic states). Preliminary observations indicate that the method yields valuable information in studying the survival of an individual's own red cells within his own body.

\section{Amount of radiation received by the recipient from injected $\mathrm{Cr}^{5111}$}

If the $\mathrm{Cr}^{51}$ which leaves the circulation becomes evenly distributed throughout all the body tissues, the circulating blood would contain the greatest concentration of $\mathrm{Cr}^{51}$. The amount of $\mathrm{Cr}^{51}$ giving no more than 0.3 rep during one week would be 320 microcuries for a subject with a blood volume of $5000 \mathrm{ml}$. (16). Preliminary data obtained in dogs indicate that one week after the transfusion of poorly preserved blood, ${ }^{12}$ the $\mathrm{Cr}^{51}$ which left the circulation was not evenly distributed throughout all the tissues, but was present in high-. est concentration in the spleen, liver, and bone marrow. The concentration of $\mathrm{Cr}^{51}$ per gram of spleen was 10 times the concentration occurring in the liver and bone marrow so that the spleen contained one-third of the injected dose. If one assumes a similar type of distribution in human subjects, an individual experiencing very rapid hemolysis of donor cells (i.e., 50 per cent or more in one day), which contained 320 microcuries, would be exposed to no more than 1.7 rep per week delivered to the spleen. In this case it would

11 The authors wish to express their appreciation to Dr. Gerald J. Hine for valuable aid and criticism in calculation of the radiation doses presented.

1285 per cent of injected cells were destroyed in one week. be the dosage received by the spleen which would be the limiting factor in the amount of $\mathrm{Cr}^{51}$ which could be safely injected. In experiments where fresh ACD blood containing 320 microcuries is transfused, the spleen of the recipient would receive no more than 0.8 rep per week. The above calculations are conservative inasmuch as it is assumed that all the $\mathrm{Cr}^{51}$ going to the spleen remained there and was not cleared from this tissue and that no $\mathrm{Cr}^{51}$ was excreted.

\section{Practical application of the radioactive chromate erythrocyte survival method}

In the light of our present information, the radioactive chromate method appears ideally suited for evaluation of immediate post-transfusion survival of erythrocytes, either freshly drawn or stored blood. The method is technically simple, highly accurate, can be performed with small aliquots of blood, allows study of the survival of an individual's own erythrocytes in his own vascular system. It makes possible transfusion studies without the hazard of transmitting virus hepatitis, and is harmless from the standpoint of the hazard of radiation.

It is of definite value in following short-term variations in erythrocyte survival and possibly may be proven to be of value in studying small changes in long-term red cell survival.

\section{SUMMARY}

1. Erythrocytes in ACD whole blood mixture combine rapidly and firmly with the radioactive chromate ion. After equilibration for three hours at 4 to $6^{\circ} \mathrm{C}$., 60 per cent was bound to the red blood cells and 90 per cent was fixed after equilibration for one hour at 25 to $26^{\circ} \mathrm{C}$. This is true of both freshly drawn blood and blood stored at $4^{\circ} \mathrm{C}$. for as long as thirty-six days. The concentration of this chromate salt shows no marked effect on the rate of $\mathrm{Cr}^{51}$ uptake within the limits of 0.25 to 9.5 micrograms. The rate of erythrocyte $\mathrm{Cr}^{51}$ uptake increased inversely with the $\mathrm{pH}$ within the observed range of 6.0 to 7.2 .

2. Post-transfusion survival as determined by the selective agglutination method of erythrocytes tagged with sodium chromate in concentrations of less than 10 micrograms per $\mathrm{ml}$. of whole blood is 2 to 10 per cent shorter than the post-transfusion 
survival of nonchromated cells. This somewhat shorter survival of the chromated cells may or may not be within the range of the normal biological variations.

3. $\mathrm{Na}_{2} \mathrm{Cr}^{51} \mathrm{O}_{4}$ released from destroyed transfused erythrocytes is not re-utilized to tag the recipient's own red blood cells.

4. The concentration of $\mathrm{Cr}^{51}$ in the circulating donor erythrocytes decreases slowly at an exponential rate with a half-life $77 \pm 12$ days. This may be due to elution of $\mathrm{Cr}^{31}$ from the circulating donor cells.

5. The survival of stored blood can be measured accurately by the chromium tagging technique for a period of forty-eight hours after transfusion without correcting for the small amount of chromium leakage. If corrections for the amount of $\mathrm{Cr}^{51}$ elution can be made, the method would allow measurement of post-transfused erythrocytes for periods of as long as three months.

\section{REFERENCES}

1. Ross, J. F., and Chapin, M. A., Effect of storage of citrated blood on the survival of transfused erythrocytes. J. A. M. A., 1943, 123, 827.

2. Ross, J. F., Finch, C. A., Peacock, W. C., and Sammons, $M$. E., The in vitro preservation and post-

- transfusion survival of stored blood. J. Clin. Invest., 1947, 26, 687.

3. Gibson, J. G., Peacock, W. C., Evans, R. D., Sack, T., and Aub, J. C., The rate of post-transfusion loss of non-viable stored human erythrocytes and the reutilization of hemoglobin-derived radioactive iron. J. Clin. Invest., 1947, 26, 739.

4. McKerns, K. W., and Denstedt, O. F., The use of sulfhemoglobin for labeling erythrocytes in Preservation of the Formed Elements and of Proteins of the Blood, C. J. Potthoff, ed., Washington, D. C., American National Red Cross, 1949, p. 4.

5. London, I. M., Shemin, D., West, R., and Rittenberg, D., Heme synthesis and red blood cell dynamics in normal humans and in subjects with polycythemia vera, sickle-cell anemia, and pernicious anemia. J. Biol. Chem., 1949, 179, 463.
6. Moore, C. V., Red cell survival measured with $C^{34}$ tagged globin in Preservation of the Formed Elements and of Proteins of the Blood, C. J. Potthoff, ed., Washington, D. C., American National Red Cross, 1949, p. 10.

7. Ross, J. F., A consideration of various techniques of evaluating post-transfusion survival of erythrocytes in Conference on Differential Agglutination of Erythrocytes, Washington, D. C., 17 Sept., 1952, Committee on Blood and Related Problems, National Research Council, Division of Medical Science.

8. Ebaugh, F. G., Ross, J. F., and Emerson, C. P., Metabolism of radioactive zinc ${ }^{\text {es }}$. To be published.

9. Gray, S. J., and Sterling, K., The tagging of red cells and plasma proteins with radioactive chromium. J. Clin. Invest., 1950, 29, 1604.

10. Sterling, K., and Gray, S. J., Determination of the circulating red cell volume in man by radioactive chromium. J. Clin. Invest., 1950, 29, 1614.

11. Lyon, W. S., Disintegration of $\mathrm{Cr}^{82}$. The Physical Rev., 1952, 87, 1126.

12. Gibson, J. G., Peacock, W. C., Seligman, A. M., and Sack, T., Circulating red cell volume measured simultaneously by the radioactive iron and dye methods. J. Clin. Invest., 1946, 25, 838.

13. Cliapin, M. A., and Ross, J. F., The determination of the true cell volume by dye dilution, by protein dilution, and with radioactive iron. The error of the centrifuge hematocrit. Am. J. Physiol., 1942, 137, 447.

14. Vazquez, O. N., Newerly, K., Yalow, R. S., and Berson, S. A., Determination of trapped plasma in the centrifuged erythrocyte volume of normal human blood with radioiodinated $\left(I^{121}\right)$ human serum albumin and radiosodium $\left(\mathrm{Na}^{24}\right)$. J. Lab. \& Clin. Med., 1952, 39, 595.

15. Emerson, C. P., The methodology of experimental transfusions and selective agglutination counting in studies on blood preservation, Washington, D. C., 17 Sept., 1952, Committee on Blood and Related Problems, National Research Council, Division of Medical Science.

16. Marinelli, L. D., Quimby, E. H., and Hine, G. J., Dosage determination with radioactive isotopes. II. Practical considerations in therapy and protection. Am. J. Roentgenol., 1948, 59, 260. 